\begin{tabular}{|l|l|}
\hline Submitted : 2021-06-28 & Accepted : 2021-07-03 \\
\hline Revised : 2021-07-01 & Published : 2021-07-19 \\
\hline
\end{tabular}

\title{
Need Analysis on The Writing Skill: What Do The Students Really Need for Writing Course?
}

\author{
Desi Wijayanti Ma'rufah*, Muflihah, Ulil Awaliyah \\ The State Islamic University of Prof. KH. Saifuddin Zuhri, Indonesia \\ *desiwijayantim@iainpurwokerto.ac.id
}

\begin{abstract}
This study aims to investigate the needs of students in writing skill. In particular, this research attempts to explore the present situation, the target and the learning needs for the writing course. A need analysis is conducted for deciding the goals and the objectives of the upcoming curriculum and for ensuring that the curriculum content ties the students' needs. A descriptive method was employed in this study. A questionnaire was used for collecting the data which then analyzed and described qualitatively. The respondents of this research were 176 students of English Education Department students who are mostly in the second semester. The results show that; firstly, in the present situation analysis, most of the students admitted that they were in the intermediate level of English; specifically, most of them have fair proficiency in writing. Next, in the target situation analysis, writing skill is the secondary need of the students in which grammar is the most priority needed by the students to be improved. Next, the students' purposes in learning English are for to be a teacher/lecturer, translator and tourism guide. Most of the students are more enjoyable for learning in the classroom that should be consisted of not more than 30 students. Thirdly, in the learning needs analysis, the students were interested to learn writing using discussion. For doing the writing task, the students require to have individual work. The learning media that is the most needed is power point presentation. In addition, the most important learning source that the students need is hand-out and the topics of the material are about issues in Indonesia. Finally, the results of this research are expected contributing to the curriculum development at the English Education Department of UIN SAIZU.
\end{abstract}

Keywords: Need analysis, students' need, writing skill 


\section{A. Introduction}

Recently, Needs Analysis (NA) in the area of English language teaching has significantly increased as interest of the study. One of the essential purposes of the need analysis is to improve the curriculum by understanding the necessary changes from the context of teaching and learning process namely students, lecturers, materials, and environment. The issue of need analysis in a classroom was conducted by many researchers to evaluate the study program. The result of need analysis is as a compulsory factor for designing the instructional material and entire component of teaching and learning process.

Tadris Bahasa Inggris (English Education Department) is a new department in UIN Prof. KH. Saifuddin Zuhri Purwokerto that has been established since 2015. Based on current situation in this study program, it showed that the institution has not provided official syllabus to the lecturers for teaching in which the learning instructions were designed by the lecturers according to their own perception or not based on the students need. This problematic issue come to be decisive to stretch attention to the stakeholders in this institution.

For that reason, to achieve the vision of the study program that in 2035 the institution has to be an excellent study program in developing English education that develops Islamic value and creates civilized society in a national level, the educators and practitioners should evaluate the current curriculum by conducting the students' need analysis. Students need analysis on English language is principally conducted with the intention of gaining deep understandings about the present and future needs of language learners from various standpoints including the lecturers with present and former students to help making well-decision on the goals and the objective of the upcoming curriculum and to confirm that the curriculum content accords the students' needs as strictly as possible (Cowling, 2007). Thus, students' need analysis is certainly significant to improve the study program 
becoming a well-developed study program in UIN Prof. KH. Saifuddin Zuhri Purwokerto.

Students' need analysis on writing skill have been conducted by many researchers; Astuti (2009); Yundayani, Emzir, \& Rafli (2017); Ampa \& Quraisy (2018); and Helaluddin, Ahmad \& Anshari (2020). However, the previous researches have not discussed the present situation, target and learning needs of English writing skill so that this study is an attempt to fill the gap of the study of needs analysis. Considering the aforementioned description of the problems in English Education Department of UIN Prof. KH. Saifuddin Zuhri Purwokerto and to achieve the vision of the study program, this study was intended to explore the students' needs on writing skill. In particular, this research attempts to study the present situation, the target situation and the learning needs for the writing course.

Moreover, need analysis determines the success or failure of the program, since it becomes the basis for the goals and objective of the programs (Richards J. , 2001). If the curriculum developer did not consider the needs of the students, the content of the curriculum would not be matched to the students. As a result, the quality of the institution will not be getting better. Hence, this study is very significantly contributing to the institution as an attempt to develop the quality of English Education Department of UIN Prof. KH. Saifuddin Zuhri Purwokerto.

\section{Need Analysis}

For educational program, students' needs analysis come to be advice for developing the curriculum. In general terms, the activities for gathering information about the students' need are called need analysis, that is especially used for designing and developing curriculum (Brown, 1995; Richards, 2001). Need analysis becomes important for ensuring the success of the program and achieving its goals which are exemplified in learning language successfully. Thus, needs analysis is a procedure to investigate the students' needs related to the learning in order to consider the learning 
process in designing and developing curriculum.

Practically, needs analysis is an influential instrument that helps explain and confirm the factual needs (Akyel \& Ozek, 2010). The results of need analysis assist the lecturer and experts to develop the curriculum relating the content of materials based on the students' needs, wants and interest (Lepetit \& Cichocki, 2005). In brief, needs analysis aims to investigate the information from various stakeholders to identify the students' needs which are as the basis of designing, developing and evaluating language curriculum program.

The scope of need analysis of this study covers present situation analysis, target situation analysis, and learning context analysis. Present Situation Analysis (PSA) tries to diagnose what the learners background at the beginning of the course (Diana \& Mansur, 2018). The sources of information in this approach are gathered from the students, the teaching establishment, and the user-institution (Jordan, 1997). The information might be in the form of language proficiency, e.g. score of placement test, background information e.g. experiences of learning English, and the other about their present abilities (Songhori, 2008). Accordingly, PSA is an approach to identify the students' background information about their proficiency, their experiences in learning English, and other students' abilities in the beginning of the course.

Target Situation Analysis (TSA) was proposed by Munby (1978) focuses on students' language needs, communicative competence specification and it could produce a sequenced syllabus design which has very detailed procedure. Indeed, TSA emphases on students' needs at the end of the language course (Robinson, 1991). In other words, TSA will inform the students' objectives for learning English, and the skills and language that the students require in the context of the target language used.

Learning Needs Analysis was proposed by Allwright (1982) is concerned to identify students' skills areas and students' preferred strategies 
of achieving the skills needed. This analysis is to recognize the strategies that learners use in learning other languages. In short, learning needs analysis concerns with the strategies, methods, techniques, materials and facilities of the learning process based on the students' background and learning objectives.

\section{Teaching Writing}

The aims of language teacher in teaching writing are to make students to produce fluent, understandable, accurate and appropriate written English. There are three stages of writing that usually provided by English teachers in writing class: (a) controlled writing, (b) guided writing, and (3) free writing (Broughton et al, cited in Hossain, 2015).

Controlled writing is an activity of writing that in the exercises, the final product and the final content is determined by the teacher. Next, Simpson (1998:1) pointed out,

'Guided writing lesson is a lesson where the teacher shows the process of writing sentence or paragraph using appropriate English rules to the students, and then they are given opportunities to use these strategies in their own work'.

Otherwise, free writing is provided when teacher only gives the title and everything is done by the students. Further, writing has three main processes involving prewriting activity, writing activity, and re-writing activity (Titisari, 2015).

Thus, teaching writing is a kind of productive skill in which the students produce the written text by applying three main processes of writing. Also, teachers can provide writing activities using the three stages. 
Desi Wijayanti Ma’rufah; Muflihah; Ulil Awaliyah

\section{B. Method}

This study aims to examine the students' needs in writing skill; specifically, this research attempts to reveal the present situation, the target situation and the learning needs for the writing course. Thus, the problems of the research are that: (1) what are the present situation analysis of English Education Department Students of UIN Prof. KH. Saifuddin Zuhri Purwokerto?; (2) what are the target situation analysis of English Education Department Students of UIN Prof. KH. Saifuddin Zuhri Purwokerto?; and (3) what are the learning needs analysis of English Education Department Students of UIN Prof. KH. Saifuddin Zuhri Purwokerto?.

A descriptive study was employed to answer the research questions. This study was conducted at English Education Department Students of UIN Prof. KH. Saifuddin Zuhri Purwokerto. In particular, the students of 2nd, 4th, 6th, 8th and former students were involved in this study. The study used questionnaire to collect the data of the research. Open and close ended questions were provided in the questionnaire. The data of needs analysis were analysed qualitatively. A descriptive analysis was conducted to analyse the data of questionnaire in which each item was analysed individually. In specifically, the students' responses to the questionnaire were classified and analysed to know the real needs. The data were analysed descriptively based on the percentage of the students' responses toward the questionnaire.

\section{Findings and Discussion}

The present study revealed the needs of English Department Students of UIN Prof. KH. Saiffudin Zuhri on writing skill. Specifically, the result show the present situation, the target and the learning needs of the students for learning writing. 


\section{Present Situation Analysis}

The present situation analysis shows the background of the students that should be considered for deciding the curriculum and instructional material. Indeed, PSA is used to recognize students' background; especially the level of language proficiency of the students before beginning the language course, and to identify their strengths and weaknesses (Robinson, 1991). This study found the students' experiences in learning English, the students' English proficiency and the students' writing ability.

Most of the students have never taken an English course. In addition, students took an English course that was not more than a year to study at the course. These findings were shown in the figure 1 and 2 .

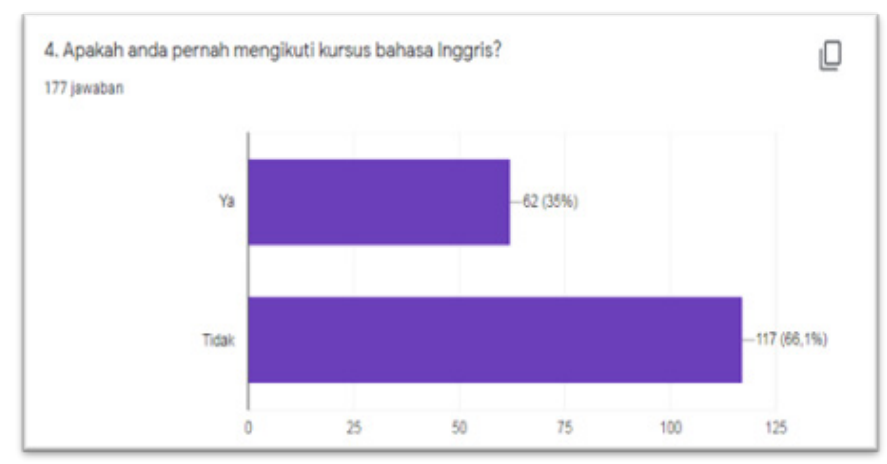

Figure 1. Students' experience of learning English

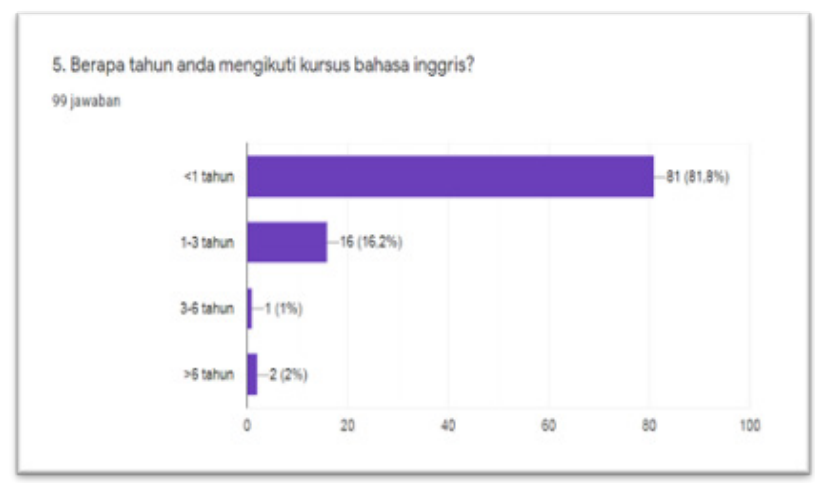

Figure 2. The length of learning English at the course 
Besides, the students assessed their English proficiency and admitted that the students have intermediate level of proficiency in English. The results show $55 \%$ of the students stated intermediate, $41.8 \%$ of the students said in the beginner level, and only $4.5 \%$ of the students assumed having advanced level of English. Figure 3 presents these findings.

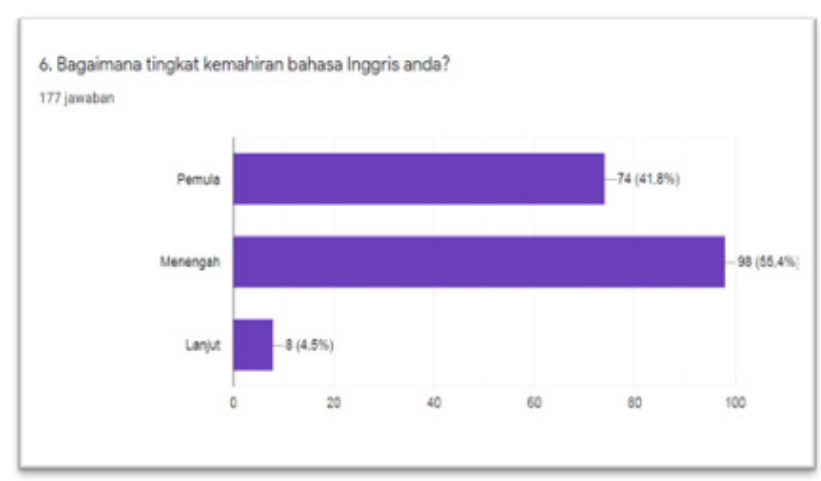

Figure 3. The students' proficiency in English

Moreover, the students claimed that they have average level of writing ability. Figure 4 shows that only $2.3 \%$ of the students who have very good writing ability, $26,6 \%$ of the students have good writing ability. $53.7 \%$ of the students stated that they have average level, $13 \%$ of students said they have poor writing ability and $4.5 \%$ of the students have very poor writing ability.

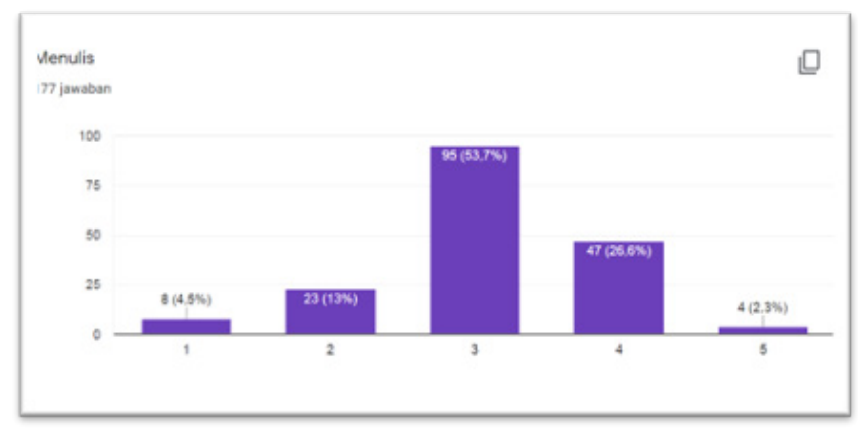

Figure 4. The level of students' writing ability 
These findings are in line with Toba, Noor, \& Sanu (2019) who revealed that the EFL students in Indonesia have good writing ability. Pratiwi (n.d) also found that the third semester students have good enough writing ability, though several weaknesses in writing have been found by students such as grammar, vocabulary and other techniques of writing. These problems may be caused by several factors. Some factors regarding this issue were revealed by Sajid \& Siddiqui (2015) that most of the schools in Indonesia have English teachers who do not have relevant degrees and have lack of methods in teaching language, especially writing skill. In addition, Keong \& Mussa (2015) points out that some students in Indonesia had never been received well writing skill before entering the college. In short, the students' writing skill at English Education Department should be improved.

\section{Target Situation Analysis}

The target situation analysis (TSA) is as an essential role for designing the goals and objectives of the curriculum. This study revealed the result of target situation analysis that cover the skill and the language feature that the students need to be improved, the students' learning purpose, and the learning environment that the students expected. As stated by Hyland (2006) target situation analysis covers the roles, skills and knowledge that students need for learning. The result of TSA will show the students' learning goals that are used to develop the whole learning components.

The finding of the study shows that writing skill is the secondary skill needed by the students in learning English. Figure 5 displays that speaking is the most needed skill by the students. 


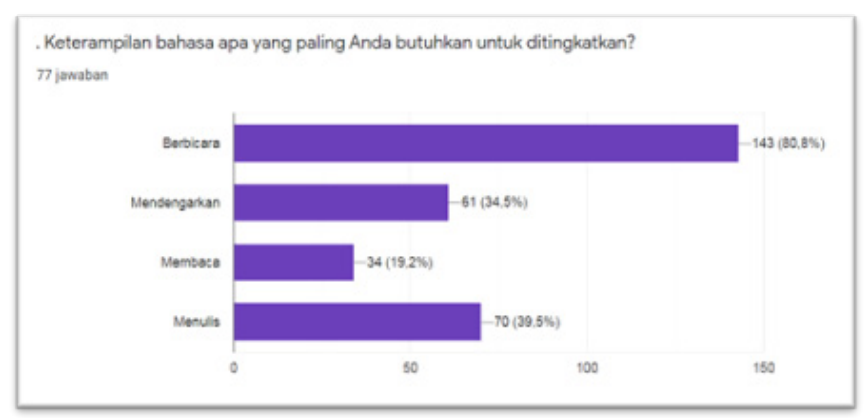

Figure 5. The most needed language skill

The current result supports Toba, Noor, and Sanu (2019) who state that Indonesian EFL students should master writing either for academic purposes or for written communication. However, writing is claimed as the hardest skill for students, because the students do not only produce the ideas but also transform the thoughts into perceived-text (Richards \& Renandya, 2002).

Furthermore, the study found that grammar is the most priority needed by the students to be improved. These results agree to Helaluddin, Ahmad, and Anshari (2020) who found that the grammar aspect becomes the most challenging aspect for students in this learning English. Sabarun (2019) also find that grammar were the most difficult thing in writing paragraph. Besides, Ariyanti \& Fitriana (2017) also reported that the EFL students in the university have problems in essay writing such as in using grammar, paragraph organization, diction, cohesion, coherence, and spelling errors. Thus, Bryne (1988) suggested that because of English as a foreign language, teacher should assist the students in using linguistic aspect in writing process. This finding is shown in figure 6. 


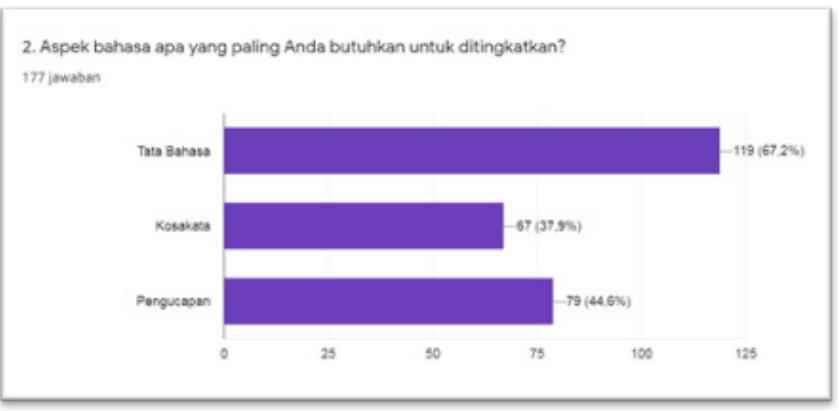

Figure 6. The most needed language aspect

Moreover, this study revealed that the majority students study English for to be a teacher/lecturer, translator and tourism guide. Writing skill is believed as the vital role for achieving the academic purposes in which the students are require to be able to write well for completing the course in the university. Mohammed and Nur (2018) point out that writing skill is needed for students in finding future work. Particularly, Martinez and Martinez (2003) also argued writing as a necessary skill for most modern jobs. The following figure displays the result of the students' purposes in learning English.

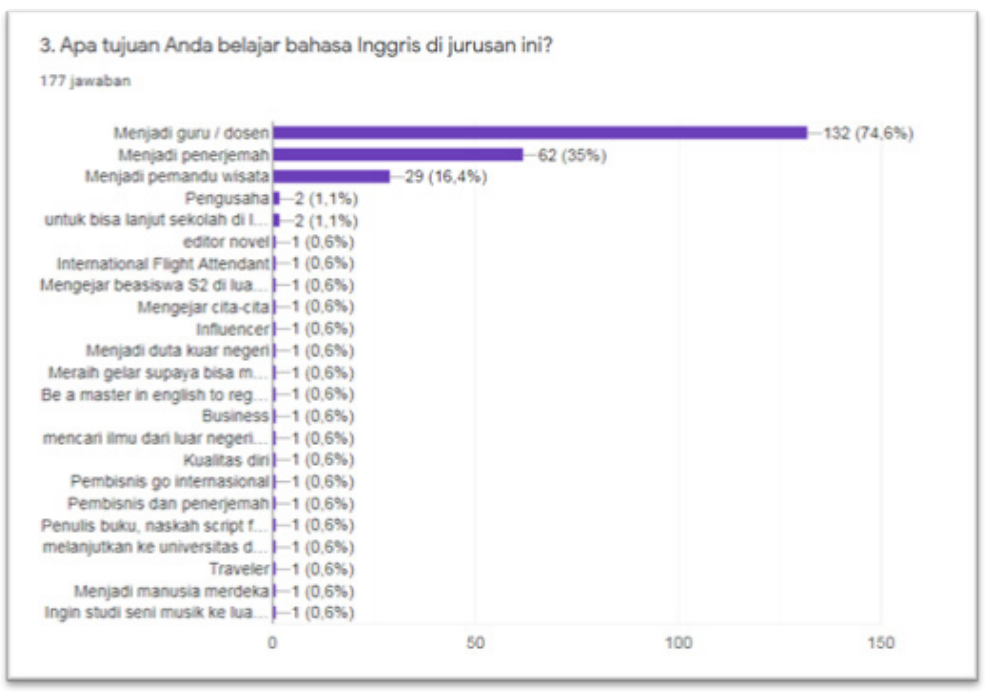

Figure 7. The students' purposes in learning English 
Desi Wijayanti Ma’rufah; Muflihah; Ulil Awaliyah

Regarding to the expected learning environment in writing course, the majority students need to study at the classroom that should be consisted of not more than 30 students. The students also admitted that they prefer to study at the classroom, not outside the classroom nor at the laboratory. These findings are shown in figure 8 and 9 .

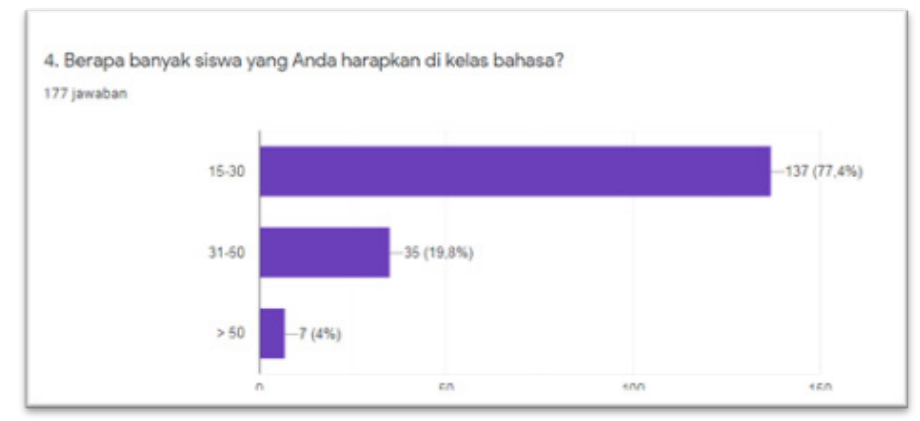

Figure 8 . The expected number of students at the class

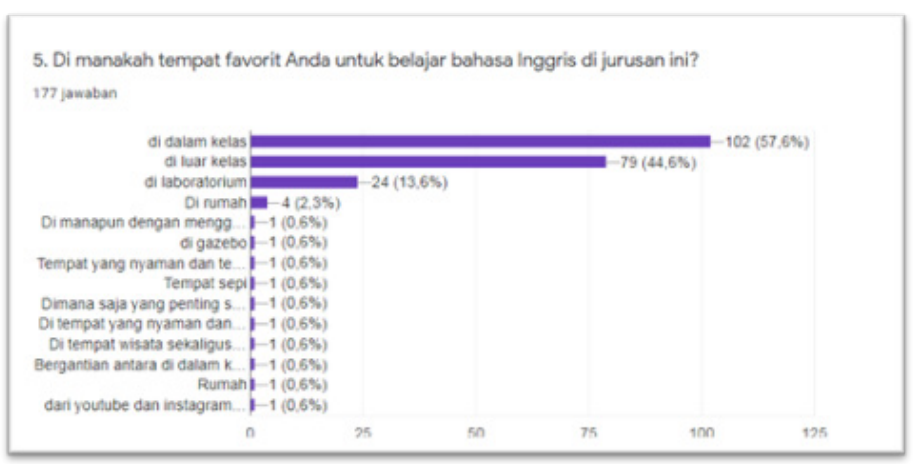

Figure 9. The expected learning environment

Astuti (2009) supported the current finding that an ideal writing classroom should be clean, comfortable, and large; furthermore, other facilities should be provided for learning such as LCD, internet access, scrap papers, stationaries, reference books and dictionaries. Similarly, regarding number of students in their writing class, Astuti (2009) also revealed that the majority of the students proposed that the class should consist of 20 students with the aim of getting necessary feedback and assistance from the 
teacher in their writing process.

\section{Learning Needs Analysis}

The learning needs analysis is to recognize the strategies that learners use in learning another language. The study revealed the learning techniques, classroom management, learning media, learning sources, topic of materials, and aspect of assessment that are expected by the students for learning writing.

The result of questionnaire indicates that the students more enjoy to learn writing using discussion. Figure 10 shows that the majority of students stated that discussion is most important technique in learning writing. Besides, presentation is the second activity that students indicated important. The following figure shows these findings.

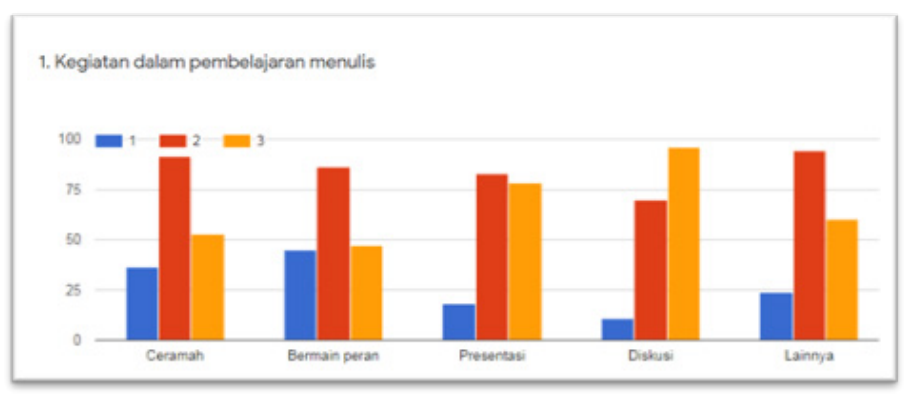

Figure 10. The expected learning techniques for learning writing

In addition, the students more require to have individual work than pair or group work. The following figure displays this result.

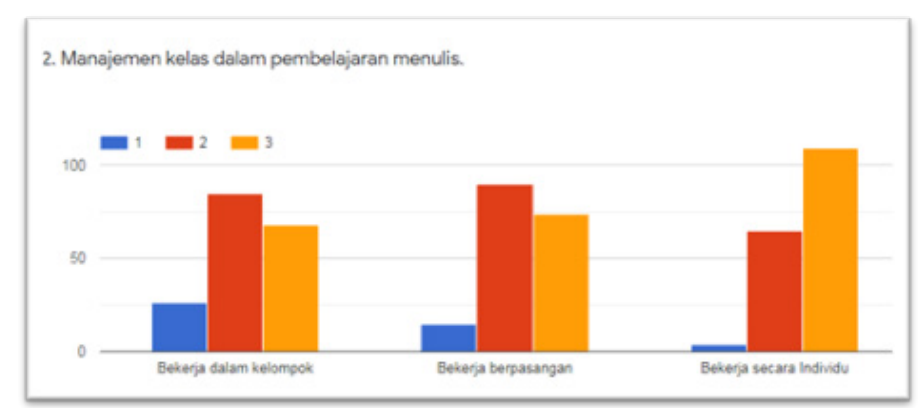

Figure 11. The expected classroom management for learning writing 
Desi Wijayanti Ma'rufah; Muflihah; Ulil Awaliyah

The three important learning media that the students need in learning writing are Power Point Presentation, YouTube and Picture. Figure 12 presents this finding.

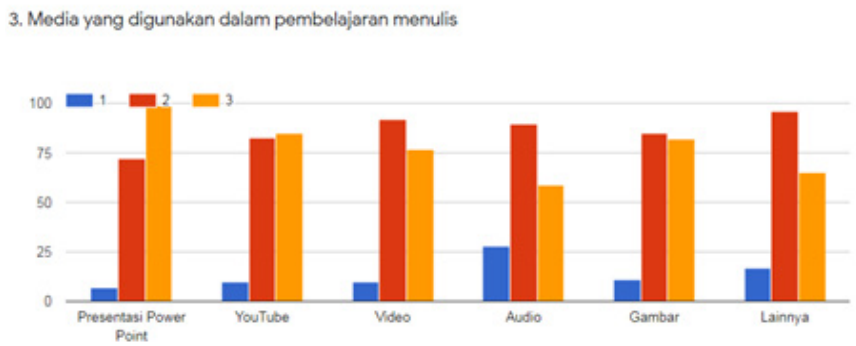

Figure 12. The expected learning media for learning writing

The three important learning sources that the students need for learning writing are hand-out, textbook and authentic materials. Meanwhile, websites, YouTube and others were indicated as less important leaning sources for students. The following figure shows these results.

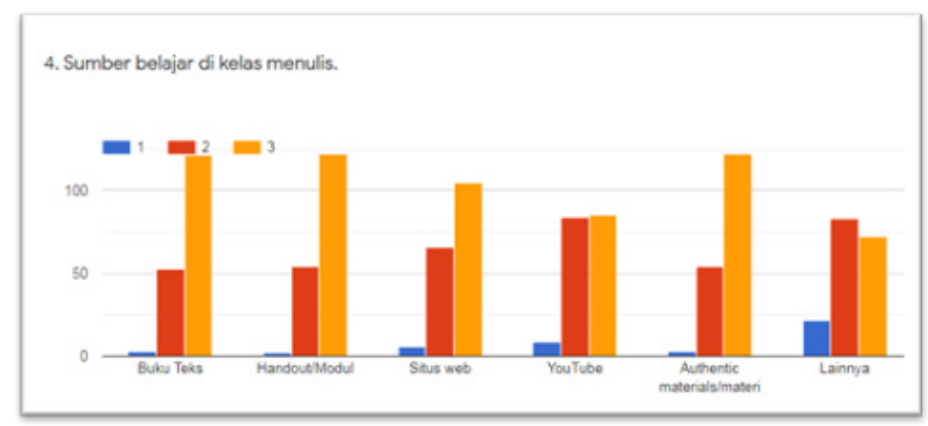

Figure 13. The expected learning sources for learning writing

The students are more interested to learn Indonesian issue as the topic of writing than to write foreign or Islamic issue. Figure 14 displays this finding. 


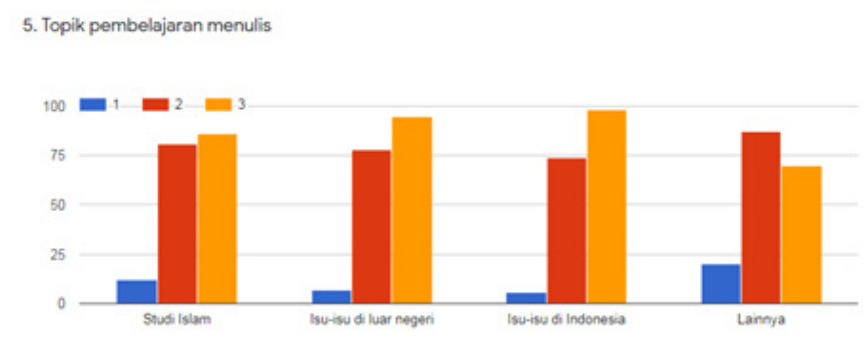

Figure 14. The expected topic of materials for learning writing

Besides, the majority of students responded that mechanics is the most important aspect in writing assessment. This result shows in the following figure.

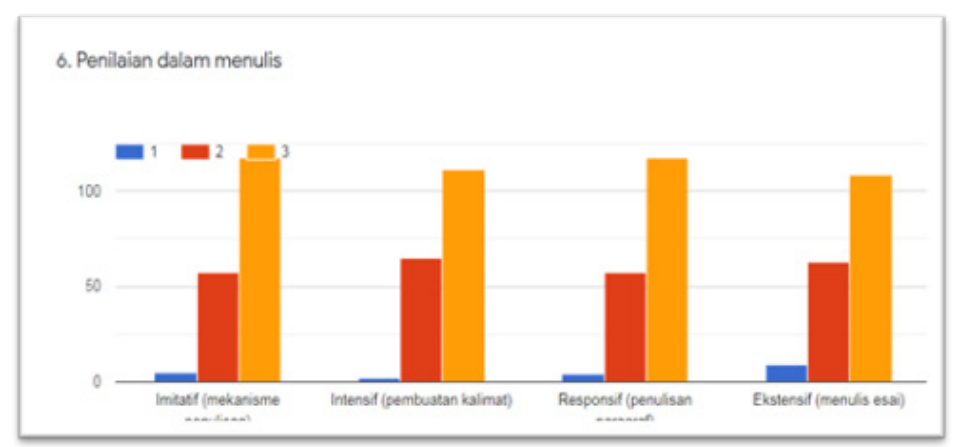

Figure 15. The expected assessment for learning writing

In line with this finding, Yundayani, Emzir, and Rafli (2017) suggest that the instructional material of writing skills for academic purposes should be based on students' needs and learning objectives. Particularly, teachers should select the instructional material that are appropriate for writing skill in academic purposes; decide the topic that are interesting, culturally acceptable and according to learning objectives; and give students opportunities for having collaborative writing. For example, mini lesson or discussion can be provided for students at the beginning or at the end of writing class in cooperative learning setting. 


\section{Conclusion}

To sum up, writing skill is one of language skill that is most needed by the students at English Education Department of UIN SAIZU. Mostly students are in the intermediate level proficiency in English in which they have fair ability in writing skill. The students' purposes in learning English are for becoming a teacher/lecturer, translator and tourism guide and grammar is the most priority needed by the students to be improved. The students require to learn writing at the classroom that consist of 15-30 students. Discussion is the most needed by the students in the learning activity and the individual practice is more enjoyable for students in doing the task. The students also want a hand-out as the learning source and power point presentation as the learning media in writing class within the topics of the material are about issues in Indonesia. The most important aspect of assessment in writing according to the students' need is the mechanics.

Lastly, the result of this study is expected to give significant benefits for the institution especially English Education Department of UIN Prof. KH. Saifuddin Zuhri Purwokerto. By recognizing the students' needs, the institution and the lecturers will be able to design and develop the curriculum, syllabus and course materials for writing class including method and assessment which match the learning and language needs. 
Need Analysis on The Writing Skill: What Do ...

\section{References}

Abudhahir, R., Mahdun, M., \& Nor, A. n.d. Need Analysis and Material Development in English for Specific Purposes in Relation to English for Islamic Studies. Journal of Management and Muamalah: 108116.

Aeni, N., Jabu, B., Rahman, M., Ismail, H., \& Bin-Tahir, S. 2018. The Students' Needs in Maritime English Class at Ami Aipi Makassar, Indonesia. Journal of Language Teaching and Research, 9(6): 12841292. http://dx.doi.org/10.17507/jtlr.0906.18.

Akyel, A., \& Ozek, Y. 2010. A Language Needs Analysis Research at an English Medium University in Turkey. Procedia Social and Behavioral Sciences, 2: 1877-0428. doi:10.1016/j/sbspro.2010.03.136.

Allwright, R. 1982. Perceiving and Pursuing Learner's Needs. Oxford: Modern English Publications.

Ampa, A.T., Quraisy, H. 2018. Needs Analysis of the English Writing Skill as the Base to Design the Learning Materials. SHS Web of Conference 42, https://doi.org/10.1051/shsconf/20184200050

Ariyanti, Fitriana, R. 2017. EFL Students' Difficulties and Needs in Essay Writing. Conference: International Conference on Teacher Training and Education 2017 (ICTTE 2017). DOI:10.2991/ictte-17.2017.4

Astuti, Puji. 2009. A Needs Analysis in Developing a Writing Curriculum for EFL Education Students: A Case Study at the Department of English Education of Semarang State University. LANGUAGE CIRCLE Journal of Language and Literature, 4(1).

Bedoya, P., Valencia, L., \& Montoya, J. 2015. Students' Needs Analysis in an EFL Program for University Professors. HOW Journal, 22(2): 1136. https://doi.org/10.19183/how.22.2.118.

Boakye, N., \& Mai, M. (2019). A Needs Analysis for a Discipline-Specific Reading Intervention. English Language Teaching, 9(3): 235-147. 
Desi Wijayanti Ma'rufah; Muflihah; Ulil Awaliyah

http://dx/doi.org/10.5539/elt.v9n3p235.

Bryne, Donn. 1988. Teaching Writing Skill. London: Longman Group Limited.

Budianto, L. 2004. Students' Needs in Learning English in the Medical Faculty of Muhammadiyah University at Malang. Jurnal Ilmu Pendidikan, 2(3): 1-9.

Cowling, J. 2007. Need analysis: Planning a syllabus for a series of intensive workplace courses at a leading Japanes company. English for Specific Purposes:426-442.

Diana, S., \& Mansur, M. 2018. Need Analysis on English Teaching Materials for ICT Students. English Teaching Learning and Research Journal, 4 (2): 209-218.

Helaluddin, Ahmad, M.A., Anshari. 2020. Need Analysis of Academic Writing Teaching Model Based on Process-genre Approach: What Do They Really Need?. Universal Journal of Educational Research, 8(10): 4728 - 4735. DOI:10.13189/ujer.2020.081043.

Hossain, M. 2015. Teaching Productive Skills to the Students: A Secondary Level Scenario (Thesis). Dhaka: BRACH University.

Hyland, K. 2006. English for academic purposes. Oxon: Routledge.

Jordan, R. 1997. English for Academic Purposes: A Guide and Resource Book for Teachers. Cambridge: Cambridge University Press.

Keong, C.Y., Mussa, H. 2015. Academic Writing Difficulties of Iraqi Postgraduate Students in Malaysia. International Journal Educational Researh, 3(6): 25-34.

Lepetit, \& Cichocki. 2005. Teaching Languages to Future Health Professionals: A Needs Assessment Study. In H. Long, Second Language Needs Analysis. UK: Cambridge University Press. Martinez, T. P., \& Martinez, A. P. 2003. The neglected "R" the need for 
writing revolution: National commission on writing in America's schools and colleges issues report. The Hispanic Outlook in Higher Education, 13: 1-5. Retrieved from http://www.collegeboard.com/ prod_downloads/writingcom/neglectedr.pdf

Mohammed, A. S. E., Nur, H.S. 2018. Needs Analysis in English for Academic Purposes: The Case of Teaching Assistants at the University of Khartoum. HOW, 25 (2): 49-68.

Munfangati, R. (2014). Investigating the Listening Needs of English Education Department Students at Universitas Ahmad Dahlan. The 61 st TEFLIN Intenational Conference: 145-148. Solo: UNS.

Pratiwi, K.D. n.d. Students' Difficulties in Writing English (A Study at The Third Semester Students of English Education Program at University of Bengkulu Academic Year 2011-2012). Unpublished thesis.

Richards, J. 2001. Curriculum Development in Language Teaching. UK: Cambrigde University Press.

Richards, J. C., \& Renandya, W. A. 2002. Methodology in Language Teaching: An Anthology of Current Practice. New York: Cambridge University Press.

Robinson, P. 1991. ESP Today: A Practitioner's Guide. Hemel Hempstead: Practice Hall.

Sabarun. 2019. Needs Analysis on Developing EFL Paragraph Writing Materials at Kalimantan L2 learners. English Language Teaching, 12(1). doi:10.5539/elt.v12n1p186

Saefullah, H. 2013. A Need Analysis for Designing an ESP-Based Syllabus in an Islamic Studies Education Program (Thesis). Bandung: Universitas Pendidikan Indonesia.

Sajid, M., Siddiqui, J.A. 2015. Lack of Academic Writing Skills in English Language at Higher Education Level in Pakistan: Causes, Effects and Remedies. International Journal of Language and Linguistics, 2(4). 
Desi Wijayanti Ma’rufah; Muflihah; Ulil Awaliyah

Simpson, C. 1998. Daily Guided Writing. New Jersey: Addison Weskey Educational Publisher Inc.

Songhori, M. 2008. Introduction to Needs Analysis. English for Specific Purposes World, 4:1-25.

Titisari, D. 2015. The Eddectiveness of Guided Writing for Teaching Writing Recount Text(Thesis). Semarang: Semarang State University.

Toba, R., Noor, W.N., Sanu, L.O. 2019. The Current Issues of Indonesian EFL Students' Writing Skills: Ability, Problem, and Reason in Writing Comparison and Contrast Essay. Dinamika Ilmu, 19 (1). doi: http:// doi.org/10.21093/di.v19i1.1506

Ulum, O. G. 2015. A Needs Analysis Study for Preparatory Class ELT Students. European Journal of English Language Teaching, 1(1): 1429. www.oapub.org/edu. 